\title{
HUKUM MEROKOK MENURUT TINJAUAN NASH DAN KAIDAH SYAR'IYAH
}

\author{
Nurlaila Harun
}

\begin{abstract}
ABSTRAK
Merokok hukumnya berdasarkan makna yang terindikasi dari Zhahir ayat Al-Qur'an dan As-Sunnah serta I'tibar (logika) yang benar. Dalil dr Al-Qur'an firman-Nya Qs. Al-Baqarah 195. Maknanya, janganlah kamu melakukan sebab yang menjadi kebinasaanmu. Wajhud dialah (aspek pendalian) dari ayat tersebut adalah merokok termasuk perbuatan mencampakkan diri sendiri kedalam kebinasaan. Sedangkan dalil dari As-Sunnah adalah Hadits yang berasal dari Rasulullah secara Shahih bahwa beliau melarang menyia-nyiakan harta. Makna menyia-nyiakan harta adalah mengalokasikan kepada hal yang tidak bermanfaat. Sebagaimana dimaklumi bahwa mengalokasikan harta dengan membeli rokok adalah termasuk pengalokasinjya kepada hal yang tidak bermanfaat bahkan pengalokasian kepada hal yang didalamnya terdapat kemudharatan.
\end{abstract}

Kata Kunci: Merokok Tinjaun Nash \& Kaidah Syari’ah

\section{A. PENDAHULUAN}

Menurut ' Abdullah bin Abdurrahman Al-Sanad, dalam bukunya Nashihah AlInsan' ala Isti'mal Al-Dukhan, rokok dikenal oleh bangsa Eropa sekitart tahun $915 \mathrm{H}$ atau 1518 M, ketika sekelompok pakar mereka menemukan tumbuhan "aneh" di Tobaco ( Meksiko). Benihnya mereka bawa pulang dan dari sana tersebar ke daerahdaerah lain, termasuk ke wilayah negeri-negeri Isam. Itu sebabnya tidak ditemukan pendapat ulama masa lalu tentang hukum merokok.

Namun, melalui pemahaman tentang maqashid al-syari'ah (tujuan agama) kita dapat mengetahui hukum merokok dan persoalan-persoalan "baru" lainnya. Tujuan tuntunan agama adalah memelihara lima hal pokok, yaitu ajaran agama, jiwa, akal, harta dan keturunan. ${ }^{1}$ Setiap aktivitas yang menunjang salah satunya, pada prinsipnya dibenarkan atau ditoleransi Islam. Dan, sebaliknya pun demikian, pembenaran itu bisa

\footnotetext{
1 Abdul Azis Syaikh bin Abdullah bin Baz, Tim Darul Haq. “ Fatwa-fatwa Terkini “, Penerjema : Musthofa ‘Aini, Lc, Penerbit Darul Haq, Jakarta 1999, hlm. 321.
} 
mengambil hukum wajib (jika tidak dilaksanakan berdosa), atau sunnah (dianjurkan, walaupun tidak berdosa bila diabaikan dan kalau dilaksanakan mendapat ganjaran), atau mubah (boleh, terserah pilihan masing-masing pribadi, tiada dosa dan tiada pahala). Sedangkan tingkat larangan ada dua : makruh (dianjurkan untuk dihindari dan ketika itu yang bersangkutan memperoleh ganjaran, tetapi jika dikerjakan tidak berdosa), dan haram (harus dihindari, dan kalau tidak, maka pelakunya terancam siksa).

Imam Al-Tirmidzi dan Ibn Majah meriwayatkan hadis serupa, tetapi redaksi akhirnya adalah: Dan ada pula hal-hal yang didiamkannya bukan karena lupa melainkan karena kasih sayang Nya, yang demikian adalah hal-hal yang dibolehkan Nya.

Ulama-ulama kontemporer banyak merujuk kepada para pakar untuk mengetahui unsur-unsur rokok, serta dampaknya terhadap manusia. Atas dasar informasi itu, mereka lalu menetapkan hukumnya.

Imam Terbesar AL-Azhar Mesir, Syaikh Mahmud Syaltut, menilai pendapat yang menyatakan bahwa merokok adalah makruh, bahkan haram, lebih dekat kepada kebenaran dan bahkan lebih kuat argumentasinya. Ada tiga alasan pokok yang dijadikan pegangan untuk ketetapan hukum ini. ${ }^{2}$ Pertama, sabdan Nabi Saw. Yang diriwayatkan oleh Imam Ahamaddan Abu Dawud dari Ummi Salamah "Terlaranglah segala sesuatu yang memabukkan dan melemaskan atau menurunkan semangat”.

Sepetri diketahui, seorang perokok akan kecanduan dengan rokok, yang terlihat dengan jelas saat ia tidak memilikinya.

Kedua, merokok dinilai oleh orang banyak ulama sebagai salah satu bentuk pemborosan. Hal ini bukan hanya oleh orang perorang yang membeli sebatang dua batang, melainkan justru oleh pabrik-pabrik rokok yang mengeluarkan biaya tidak kecil untuk memprogandakan sesuatu yang tidak bermanfaat, kalau enggan berkata membahayakan. Juga pada biaya pengobatan bagi mereka yang menderita sekian banyak penyakit akibat rokok. Agama melarang segala bentuk pemborosan. Jagankan

2 M. Shihab Quraish. "Fatwa-fatwa Seputar Wawasan Agama”, Diterbitkan oleh Penerbit Mizan Anggota IKAPI, Bandung 1999. hlm., 44. 
dalam hal yang buruk, atau tidak bermanfaat, dalam hal yang baik pun dilarangnya. ${ }^{3}$ “ Tiada pemborosan dalam kebaikan dan tiada kebaikan dalam pemborosan," demikian sabda Nabi Saw.

Ketiga, dari segi dampaknya terhadap kesehatan. Mayoritas dokter, bahkan Negara, telah mengakui dampak buruk ini, sehingga seandainya tidak ada teks keagamaan (ayat atau hadis) yang pasti menyangkut larangan merokok, maka dari segi maqashid al-syari'ah sudah cukup sebagai argumentai larangannya.

Tiga dasar pemikiran diatas mengantarkan banyak ulama kontemporer kepada kesimpulan haramnya atau paling tidak makruhnya merokok. Saya cenderung untuk mempeketat larangan ini.

Merorok dimasjid terlarang karena aromanya dapat menganggu orang lain, apalagi bila diakui bahwa perorokok pasif pun dapat terganggu ${ }^{4}$. Larangan ini dianologikan dengan sabda Nabi Saw, "siapa yang memakan bawang putih atau merah, hendaklah ia menjauhi kami atau menjauhi masjid kami."

Kalau bawang yang secara jelas tidak haram bahkan dalam hal-hal tertentu boleh jadi membawa dampak positif bagi kesehatan terlarang pemakannya untuk mendekati masjid (karena masjid adalah tempat umum), maka adalah lebih wajar jika yang merokok pun dilarang untuk mendekati tempat-tempat umum. Terlepas apakah ia mengganggu kesehatan atau tidak. ${ }^{5}$

Lancet, sebuah majalah kedokteran yang terbit di Inggris menyatakan bahwa merokok itu penyakit,bukan kebiasaan. Perilaku ini merupakam bencana yang dialami oleh kebanyakan anggota keluarga, juga sebagai kebiasaan yang dapat menurunkan kehormatan seseorang. Jumlah orang yang mati disebabkan merokok itu berlipat ganda. Mereka menyimpulkan bahwa asap rokok lebih berbahaya daripada asap mobil. Dan

\footnotetext{
${ }^{3}$ Bachtiar, Harsya,. “Islam dan Nestapa Manusia Modern.” Terjemahan Anas Mahyuddin dari Islam and the Plight of Modern Man", Penerbit : Bandung Pustaka, 1983., hlm. 94.

${ }^{4}$ Mas' ufi F, Masdar, "Shalat, dalam Kontestualisasi Doktrin," Penerbit Paramadina, Jakarta, 1994., hlm. 40.

5 Ahmad Al-Mubarak Al-Huraibi, dalam bukunya "Atsar Al-Mukhaddarat Wa Al-Musakkirat Wa Al-Tadkhin fi Al-Shi hhah Wa Al-Din”,. (hlm.37 dan 48). Wallahu a'lam. Sementara Ulama memfatwakan bahwa perokok, walaupun belum kecanduan, tidak dibenarkan menjadi imam dalam shalat, dan kalaupun ia menjadi imam, sholat orang-orang yang mengikutinya menjadi tidak sah.
} 
dokter memberi nasihat bahwa orang yang merokok itu tidak aman dalam menjalankan tugasnya.

Di Indonesia yang mati mencapai 200rb-400rb tiap tahun karena pecandu rokok Pajak rokok 180 triliun disumbangkan dari orang yang membeli rokok. Tetapi sumbangan perusahaan/industri rokok kepada perokok, hanya asapnya.

Tumbuhan yang dikenal dengan nama ad dukhan atau tembakau baru dikenal pada akhir abad ke-10 Hijriah. Dan semenjak digunakan manusia, para ulama pada zaman itu dituntut untuk membicarakannya menurut keterangan hukum syara'. Sebagian berpendapat haram; sebagian berpendapat makruh; sebagian lagi mengatakan boleh(mubah), dan sebagian lagi tidak memberikan hukum secara mutlak, tetapi menetapkan hukumnya secara rinci, ${ }^{6}$.dan sebagian lagi dari mereka (ulama) berdiam diri, tidak membicarakannya.

\section{B. PEMBAHASAN}

\section{Dalil-dalil Golongan yang Mengharamkan}

Memabukkan

Mereka mengatakan bahwa rokok itu memabukkan, sedangkan tiap-tiap yang memabukkan itu hukumnya haram.. Yang dimaksud dengan memabukkan ialah segala sesuatu yang dapat menutup akal, meskipun hanya sebatas tidak ingat (dialami oleh orang-orang yang pertama kali melakukannya). Artinya,merokok bisa menjadikan pikirannya kacau, menghilangkan pertimbangan akalnya, menjadikan nafasnya sesak dan dapat teracuni. Mabuk dalam hal ini bukan mabuk karena lezat, dan bukan pula menggigil.

Sedangkan sebagian dari mereka tidak memperbolehkan orang yang merokok itu menjadi imam. ${ }^{7}$

${ }^{6}$ Nurcholis Madjid, “ Islam Doktrin dan Peradaban: Sebuah Telaah Kritis tentang Masalah Keimanan dan Komederenan”, Penerbit: Yayasan Paranmadina , 1992, hlm., 110.

7 Amidhan, “Dilema Kesejahteraan Umat, dalam Kehampaan Spritual Masyarakat Modern”, Penerbit Mediacita, Jakarta, 2000, hlm,. 180. Dalil dari As-Sunnah- Hadits Rasulullah Saw yang berbunyi Tidak boleh (menimbulkan) bahaya dan juga tidak boleh membahayakan orang lain. Jadi menimbulkan (haram) adalah ditiadakan (tidak berlaku) dalam syari'at, baik bahayanya terhadap badan, ataupun harta. Sebagaimana pula bahwa merokok adalah berbahaya terhadap badan dan harta. Adapun 


\section{Melemahkan Badan}

Mereka berkata,'Kalaupun merokok itu tidak sampai memabukkan, minimal perbuatan itu dapat menyebabkan tubuh menjadi lemah dan loyo. Dari Ummu Salamah r.a.:"Bahwa Rasulullah saw. melarang segala sesuatu yang memabukkan dan melemahkan." (HR Ahmad dan Abu Daud).

Menimbulkan Mudharat

1. Mudharat pada badan: menjadikan badan lemah, wajah pucat, terserang batuk, bahkan dapat menimbulkan penyakit paru-paru.

2. Mudharat pada harta, yang dimaksud ialah bahwa merokok itu menghamburhamburkan harta, yakni menggunakannya untuk sesuatu yang tidak bermanfaat bagi badan dan ruh, tidak bermanfaat di dunia dan akhirat. ${ }^{8}$ Sedangkan Nabi saw. Telah melarang membuang-buang harta, Allah Swt berfirman:”...dan janganlah kamu menghambur-hamburkan (hartamu) secara boros. Sesungguhnya pemboros-pemboros itu adalah saudara-saudara setan dan setan itu adalah sangat ingkar kepada Tuhannya." (Al Isra (17) ayat :26-27)9

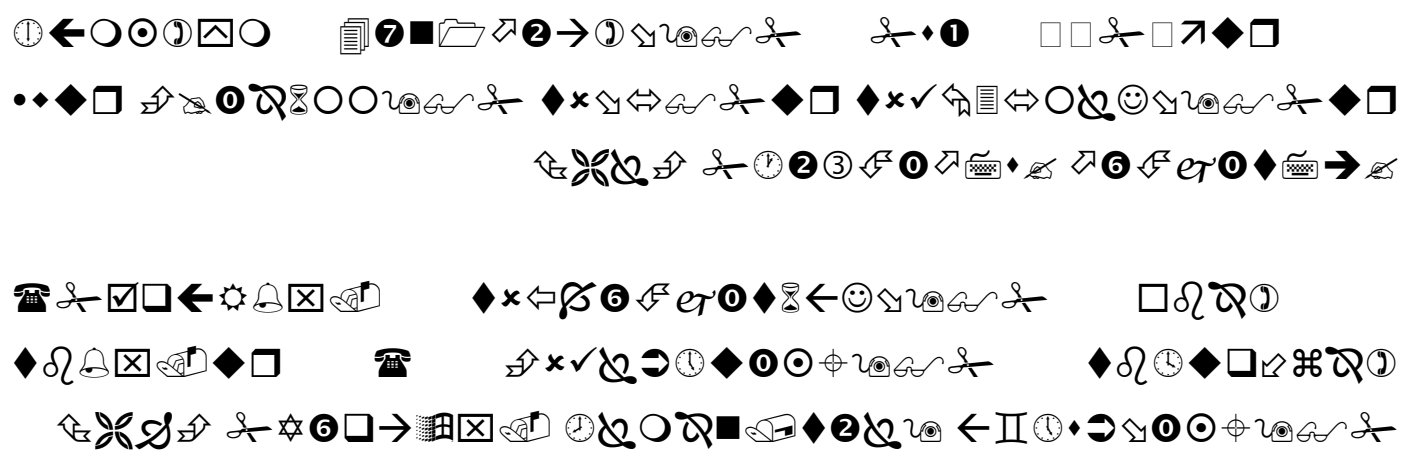

dalil dari I'tibar (logika) yang benar yang menunjukkan keharaman merokok adalah keras (dengan perbuatannya itu) si perokok mencampakkan dirinya sendiri kedalam hal yang menimbulkan hal yang berbahaya, rasa lemas dan keletihan jiwa. hlmn, 79.

${ }^{8}$ Lubis, Nur. A. Fadli “ Kesehatan Dan Mental “, Penerbit Grafiti PRESS, Jakarta., 1989,

9 “Tohaputra Ahmad H.Drs., “Al-Qur'an Dan Terjemahnya” Penerbit CV. As Syifa, Semarang, 2000. h : 609 . 
26. Dan berikanlah kepada keluarga-keluarga yang dekat akan haknya, kepada orang miskin dan orang yang dalam perjalanan dan janganlah kamu menghamburhamburkan (hartamu) secara boros.

27. Sesungguhnya pemboros-pemboros itu adalah Saudara-saudara syaitan dan syaitan itu adalah sangat ingkar kepada Tuhannya.

Salah seorang ulama berkata: "Bila seseorang sudah mengakui bahwa ia tidak menemukan manfaat rokok sama sekali, maka seharusnya rokok itu diharamkan, bukan dari segi penggunaannya, tetapi dari segi pemborosan. ${ }^{10}$ Karena menghamburhamburkan harta itu tidak ada bedanya, apakah dengan membuangnya ke laut atau dengan membakarnya, atau dengan merusaknya." 11

\section{Alasan Golongan yang Memakruhkan}

1. Bahaya, merokok itu tidak lepas dari dharar (bahaya), lebih-lebih jika terlalu banyak melakukannya. Sedangkan sesuatu yang sedikit itu bila diteruskan akan menjadi banyak.

2. Mengurangkan harta. Dapat mengurangkan harta yang dapat digunakan untuk hal-hal yang lebih baik dan lebih bermanfaat bagi sahabatnya dan bagi orang lain.

3. Bau dan asapnya mengganggu serta manyakiti orang lain yang tidak merokok.

4. Menurunkan harga diri/wibawa bagi orang yang mempunyai kedudukan sosial terpandang.

10 Rakhmat, Jalaludin, dan Abdullah M. Amin , “Kesehan dan "Islam Alternatif”, Penerbit: Wacana Mulia, Bandung, Mizan, 1991, hlm. , 63. Orang yang berakal tentu tidak rela hal itu terjadi terhadap dirinya sendiri. Alangkah tragisnya kondisi dan demikian sesak dada siperokok bila dirinya tidak menghisapnya. Alangkah berat dirinya berpuasa dan melakukan ibadah-ibadah lainnya karena hal itu menghalangi dirinya dari merokok. Bahkan alangkah berat dirinya berinteraksi dengan orang-orang yang shalih karena tidak mungkin mereka membiarkan rokok mengepul dihadapan mereka.

${ }^{11}$ Al-Mawardi Al-Imam, "Kenikmatan Kehidupan Dunia dan Agama”, Penerjemah Kamaluddin .,Penerbit Dar Ibn Katsir, Beirut Judul Asli Adabud Dun ya Wad din. Penulis Al-Imam AlMuhammd, Cetakan Pertama, Maret 2001, Jakarta., hlm., 481. 
5. Dapat melalaikan seseorang untuk beribadah secara sempurana.

6. Bagi orang yang biasa merokok, akan membuat pikirannya kacau jika pada suatu saat ia tidak mendapatkan rokok.

7. Jika perokok menghadiri suatu mejelis/pertemuan, ia akan mengganggu orang lain, maka hendaklah ia malu melakukannya.

Syekh Abu Sahal Muhammad bin Al Wa'izh Al Hanafi berkata: “Kemakruhan bagi perokok disebabkan menjadikan pelakunya hina dan sombong, memutuskan hak dan keras kepala. Selain itu, segala sesuatu yang baunya mengganggu orang lain adalah makruh, ${ }^{12}$ sama halnya dengan memakan bawang. Maka asap rokok yang memiliki dampak negative ini lebih utama untuk dilarang, dan perokoknya lebih layak dilarang masuk mesjid serta menghadiri pertemuan-pertemuan."

\section{Alasan Golongan yang Memperbolehkan}

Golongan ini berpegang pada kaidah bahwa asal segala sesuatu itu boleh, sedangkan anggapan bahwa rokok itu memabukkan atau menjadikan lemah itu tidak benar. Memang benar bahwa orang yang tidak biasa merokok akan meraskan mual bila ia pertama kali melakukannya, tetapi hal ini tidak menjadikan haram. Jika orang menganggap merokok sebagai perbuatan israf, maka hal ini tidak hanya terdapat pada rokok.

Syekh Mushthafa As Suyuthi Ar Rabbani berkata: "Setiap orang yang mengerti tentang pokok-pokok agama dan cabang-cabangnya, yang mau bersikap objektif, apabila sekarang ia ditanya tentang hukum merokok ----setelah rokok dikenal banyak orang serta banyaknya anggapan yang mengatakan bahwa rokok dapat membahayakan akal dan badan---- niscaya ia akan memperbolehkannya. Sebab asal segala sesuatu yang tidak membahayakan dan tidak ada nash yang mengharamkannya adalah halal dan mubah, sehingga ada dalil syara' yang mengharamkannya. ${ }^{13}$

\footnotetext{
${ }^{12}$ Ibid., h., 66.

13 Al-Halawi Muhammad Abdul Aziz., "Fatwa Dan Ijtihad Umar Bin Khattab Ensiklopedi Berbagai Persoalan Fiqh”, Penerbit Risalah Gusti Cetakan Pertama, Diterjemahkan Wasmuka Ust. Zubeir Suryadi Abdullah Surabaya,1999. hlm. 419.
} 
Inilah pendapat yang dikemukakan Syekh Mushthafa yang didasarkan pada kenyataan yang terjadi pada zaman beliau. Seandainya beliau mengetahui bahaya yang ditimbulkannya seperti yang tampak pada hari ini, niscaya dengan penuh keyakinan beliau akan mengubah pendapatnya.

\section{Golongan yang Merinci Pendapatnya}

Golongan ini mengatakan bahwa sesungguhnya tumbuhan ini (tembakau) pada dasarnya adalah suci, tidak memabukkan, tidak membahayakan, dan tidak kotor. Jadi, pada asalnya adalah mubah, kemudian berlaku padanya hukum-hukum syariat seperti berikut:

(1) Barangsiapa yang menggunakannya tetapi tidak menimbulkan mudharat pada badan atau akalnya, maka hukumnya adalah jaiz (boleh).

(2) Barangsiapa yang apabila menggunakannya menimbulkan mudharat, maka hukumnya haram, seperti orang yang mendapatkan mudharat bila menggunakan madu.

(3) Barangsiapa yg memanfaatkannya untuk menolak mudharat, semisal panyakit, maka wajib manggunakannya.

Jadi, hukum-hukum ini ditetapkan berdasarkan sesuatu yang akan ditimbulkannya, sedangkan pada asalnya adalah mubah, sebagaimana yang telah kita ketahui.

\section{Pendapat Ulama Mutaakhkhirin}

Syekh Hasanain makhluf, mufti Mesir, yang menginventarisasi pendapat sebagian ulama sebelumnya, berpendapat bahwa hukum rokok adalah mubah. Beliau juga mengatakan bahwa keharaman dan kemakruhannya apabila timbul faktor-faktor lain, seperti jika menimbulkan mudharat baik banyak atau sedikit terhadap jiwa maupun harta. Atau karena mendatangkan mafsadat dan mengabaikan hak istri dan anakanaknya atau orang yang nafkahnya menjadi tanggungannya manurut syara'. Apabila terdapat unsure-unsur seperti ini maka hukumnya menjadi makruh atau haram, sesuai 
dengan dampak yang ditimbulkannya. Sebaliknya, jika tidak terdapat dampak negative seperti itu, maka hukumnya halal. ${ }^{14}$

Syekh Muhammad Ibnu Mani’ (Ulama Arab Saudi), berkata di dalam kitabnya ghayatul Muntaha, sebagai berikut: "Pendapat yang memperbolehkan rokok adalah pendapat orang yang mengigau sehingga tidak perlu dihiraukan. Di antara mudharat yang ditimbulkannya ialah merusak badan, menimbulkan bau yang kurang sedap dan mengganggu orang lain, serta dapat menghambur-hamburkan harta tanpa ada gunanya. Maka janganlah anda terperdaya oleh perkataan orang-orang yang menganggapnya mubah. Sebab, setiap orang boleh diambil atau ditolak perkataannya, kecuali Rasulullah Saw. Yang tidak boleh ditolak perkataannya.

Barangkali pendapat yang paling adil dan paling sahih alasannya dalam masalah ini ialah pendapat yang dikemukakan oleh Al Maghfur Syekhul Akbar Mahmud Syaltut, Rektor Al Azhar, di dalam kitab beliau: "Kalaupun tembakau tidak menjadikan mabuk dan tidak merusak akal, tetapi masih menimbulkan mudharat yang dapat dirasakan pengaruhnya pada kesehata orang yang merokok dan yang tidak merokok. Para dokter telah menjelaskan bahwa unsure-unsur yang ada didalamnya diketahui mengndung racun. Karena itu tidak diragukan lagi bahwa tembakau (merokok) dapat menimbulkan gangguan dan mudharat, sedangkan hal ini merupakan sesuatu yang buruk dan terlarang menurut pandangan Islam. Disisi lain, pengeluaran belanja untuk rokok ternyata lebih banyak, padahal anggaran tersebut dapat digunakan untuk sesuatu yang lebih baik dan bermanfaat. Maka dari sudut pandang ini merokok jelas-jelas dilarang dan tidak diperbolehkan syara'.

${ }^{14}$ Budi Utomo Setiawan Dr., “ Fiqh Actual Jawaban Tuntas Masalah Kontemporer "Pengantar :Dr. H.M. Hidayat Nur Wahid Penerbit GEMA INSANI PRESS Anggota IKAPI Cetakan Pertama Sya'ban 1424 H/Oktober 2003 M. hlm. 209.. Topik ini relative menjadi wacana yang baru, sehingga belum ada ketetapan hukum Syari'ah dan para fuqaha klasik dalam berbagai mazhab, disamping belum sempurnanya gambaran tentang substansi masalah dan dampak rokok berdasarkan riset kesehatan yang akurat. Maka wajar setelah itu terjadilah perbedaan pendapat dari berbagai mazhab fiqih tentang masalah ini. Sebagaian berpendapat Haram, sebagian berpendapat Makruh, sebagian lagi mengatakan boleh (mubah) dan terutama para Ulama yang terlanjur mengkomsumsi dan sebagian lagi tidak memberitahu hukum secara mutlak, tetapi menetapkan hukumnya secara rinci., Bahkan sebagian lagi dari mereka berdiam diri, tidak mau membicarakannya. 
Padahal perlu di ketahui bahwa Syekh Syaltut Rahimahullah terkena cobaan berupa kebiasaan merokok yang dilakukannya sejak muda sehingga beliau tidak dapat membebaskan diri daripadanya. Tetapi karena kesadarannya, beliau menguatkan pendapat yang mangharamkan rokok, sebab menerapkan 'illat-illat hukum dan kaidahkaidah tasyri' yang umum.

\section{Penilaian dan Tarjih}

Tampak bahwa perbedaan pendapat ulama dari berbagai mazhab sebagaimana yang telah dikutip di atas bukanlah terletak pada dalil-dalil yang mereka kemukakan, tetapi hanya dalam hal penerapannya. Artinya, mereka sepakat bahwa apa saja yang menimbulkan mudharat pada badan atau akal terhukum haram, tetapi mereka berbeda pandangan dalam menerapkan hukum ini terhadap rokok. Apabila mereka secara keseluruhan menegaskan adanya dharar (bahaya) pada rokok, niscaya mereka akan sepakat mengharamkannya, tanpa perdebatan.

Adapun jika ada sebagian orang yang merasa mendapatkan ketenangan karena merokok, maka hal ini bukanlah termasuk manfaat rokok, tetapi hanya karena ia telah terbisa merokok dan kecanduan. Orang seperti ini hanyalah memikirkan kesenangan dan ketenangan tanpa mau tahu bahaya panyakit yg mengancam dirinya apalagi orang lain.

Imam Ibnu Hazm berkata, bahwa perbuatan israf itu haram, maksud israf yaitu berbuat boros pada sesuatu yang tidak diperlukan, dan menghambur-hamburkan harta secara sia-sia, meskipun dalam jumlah kecil. Allah berfirman:

“... dan janganlah kamu berlebih-lebihan. Sesungguhnya Allah tidak menyukai orang-orang yang berlebih-lebihan. ” (Al An'am (06) ayat : 141)

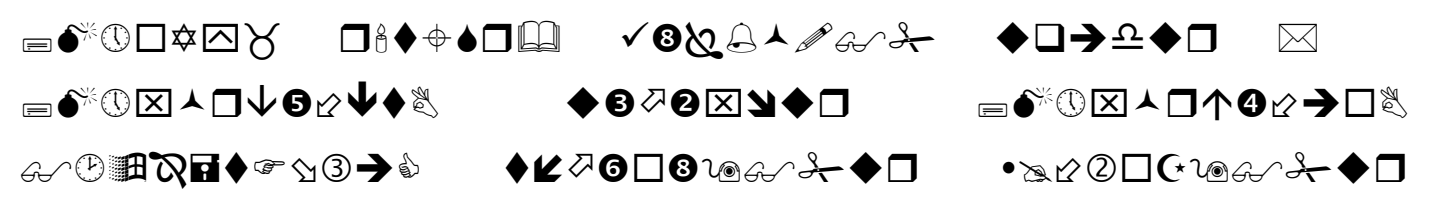

15 “Al-Qui'an Dan Terjemahnya.”, Op. Cit., hlm. 307. 


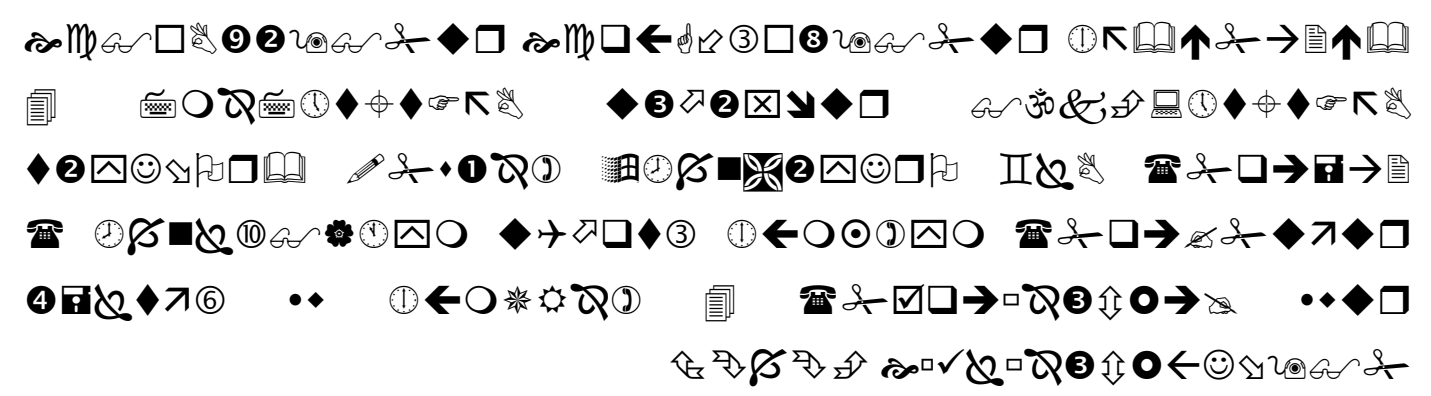

Dan dialah yang menjadikan kebun-kebun yang berjunjung dan yang tidak berjunjung, pohon korma, tanam-tanaman yang bermacam-macam buahnya, zaitun dan delima yang serupa (bentuk dan warnanya) dan tidak sama (rasanya). Makanlah dari buahnya (yang bermacam-macam itu) bila dia berbuah, dan tunaikanlah haknya di hari memetik hasilnya (dengan disedekahkan kepada fakir miskin); dan janganlah kamu berlebih-lebihan. Sesungguhnya Allah tidak menyukai orang yang berlebih-lebihan.

\section{PENUTUP}

Syaria'at Islam sesuai untuk setiap zaman dan tempat, " demikianlah keyakinan setiap Muslim. Oleh karena itu, berbagai persoalan baru yang muncul pasti ada pemecahannya di dalam syariat islam, meskipun persoalan-persoalan baru tersebut sebelumnya tidak pernah terlintas di benak para pakar hukum Islam, terutama para mujtahid generasi awal.

Pandangan Islam tentang merokok serta kategori apa ia ditempatkan dari kelima tingkatan hukum diatas, ditentukan oleh sifat rokok serta dampak-dampaknya bagi kelima tujuan pokok agama. Sebagian ulama cenderung menilai rokok sebagai sesuatu yng mubah. Ini disebabkan mereka tidak atau belum mengetahui dampak negative dari rokok. Dalam hal ini, mereka berpegang pada sebuah riwayat yang dikemukakan oleh Al-Daruquthni dan Abu Nu'aim bahwa Nabi Saw, bersabda: "Sesungguhnya Allah telah mewajibkan kewajiban-kewajiban, maka jangan abaikan kewajiban itu. Dan 
menetrapkan batas-batas, maka jangan melampauinya. Serta mengharamkan hal-hal, maka jangan mendekatinya, dan meninggalkan (tidak menyebut) hal-hal, bukan karena lupa, karena itu jangan kamu membahasnya".

DAFTAR PUSTAKA 
Ahmad Tohaputra, Al-Qur'an Dan Terjemahnya, Semarang: Penerbit CV. As Syifa, 2000 .

Abdullah Bin Baz Abdul Azis Syaikh bin, Tim Darul Haq, Fatwa-fatwa Terkini, Penerjemah: Musthofa ‘Aini, Lc, Penerbit Darul Haq, Jakarta 1999.

Abdul Aziz Al-Halawi Muhammad, Fatwa Dan Ijtihad Umar Bin Khattab Ensklopedi Berbagai Persoalan Fiqh, Penerbit Risalah Gusti

Harsya Bachtiar, Islam dan Nestapa Manusia Modern, Bandung: Bandung Pustaka, 1983.

Fadli A.Lubis, Nur, Kesehatan Dan Mental, Jakarta: Penerbit Grafiti PRESS, 1989.

Imam Al-Mawardi, Kenikmatan Kehidupan Dunia dan Agama, Penerjemah Kamaluddin., Penerbit Dar Ibn Katsir, Beirut Judul Asli Adabud Dun ya Wad din . Penulis Al-Imam Al-Muhammd, Cetakan Pertama, Maret 2001, Jakarta.

Jalaluddin Rakhmat dan Abdullah M. Amin , Kesehatan dan "Islam Alternatif", Penerbit : Wacana Mulia, Bandung, Mizan, 1991.

Mas'ufi F, Masdar , Shalat dalam Kontestualisasi Doktrin Penerbit Paramadina, Jakarta, 1994.

Mubarak Al Ahmad Al-Huraibi, dalam bukunya "Atsar Al-Mukhaddarat Wa AlMusakkirat Wa Al-Tadkhin fi Al-Shi hhah Wa Al-Din”

Madjid Nurcholis, Islam Doktrin dan Peradaban: Sebuah Telaah Kritis tentang Masalah Keimanan dan Komederenan”, Penerbit: Yayasan Paramadina , 1992.

W. Amidhan, “ Dilema Kesejahteraan Umat, dalam Kehampaan Spritual Masyarakat Modern”, Penerbit Mediacita, Jakarta, 2000.

Quraish M. Shihab, “Fatwa-fatwa Seputar Wawasan Agama”, Diterbitkan oleh Penerbit Mizan Anggota IKAPI, Bandung 1999. 